Original Research Paper

\title{
Antidiabetic and Antioxidant Potential of Vernonia amygdalina Leaf Extract in Alloxan-Induced Sprague-Dawley Rats
}

\author{
${ }^{1}$ Fatmawaty Yazid, ${ }^{1}$ Nina Bonita Hasanah, ${ }^{1}$ Rosmalena, ${ }^{2}$ Muhammad Hanafi and ${ }^{3}$ Vivitri Dewi Prasasty \\ ${ }^{1}$ Department of Medical Chemistry, Faculty of Medicine, Universitas Indonesia, Jakarta, Indonesia \\ ${ }^{2}$ Research Center for Chemistry, The Indonesian Institute of Sciences, South Tangerang, Banten, Indonesia \\ ${ }^{3}$ Faculty of Biotechnology, Atma Jaya Catholic University of Indonesia, Jakarta, Indonesia
}

\author{
Article history \\ Received: $12-09-2020$ \\ Revised: 16-11-2020 \\ Accepted: 19-11-2020 \\ Corresponding Author: \\ Vivitri Dewi Prasasty \\ Faculty of Biotechnology, \\ Atma Jaya Catholic University \\ of Indonesia, Jakarta, Indonesia \\ Email: vivitri.dewi@atmajaya.ac.id
}

\begin{abstract}
The treatment of diabetes mellitus using drug medications have side effects such as weight gain, hypoglycemia, the risk of cardiovascular or all-cause mortality. These limitations have become one reason to use complementary therapy from plant extract, such as Vernonia amygdalina as an antidiabetes. This research aimed to investigate the effect of $V$. amygdalina leaf extracts as antidiabetic and antioxidant agents by measuring the fasting Blood Glucose Levels (BGLs), $\mathrm{IC}_{50}$ value and the profiles of phytochemical constituents using LC-MS analysis. We used 24 Sprague-Dawley rats (200-300 g) divided into six groups: normal group, positive control group and negative control group. The other three groups were leaf extract groups in different doses: 200, 400 and $600 \mathrm{mg} / \mathrm{kg} \mathrm{BW}$ dose of leaf extract groups, respectively. The antidiabetic effects were tested based on BGLs were observed for 16 days and examined on day 4, 8, 12 and 16. The rat renal histological changes were observed under an electron microscope using Hematoxylin Eosin (HE) dye. V. amygdalina leaf extract showed an effect in reducing BGL on diabetic rats with an effective dose of 200 $\mathrm{mg} / \mathrm{kg}$. Renal histopathology result showed necrosis on proximal tubules in all treatment except the normal group. In conclusion, the administration of $V$. amygdalina leaf extract can reduce BGL. However, it did not show any improvement in the histopathological structure of the kidney.
\end{abstract}

Keywords: Diabetes, Blood Glucose Levels, Vernonia amygdalina, Renal Histopathology

\section{Introduction}

Diabetes is a chronic disease caused by the pancreas inability to produce enough insulin hormones or ineffective use of insulin hormones in the body. Based on the data from research of basic health (Riskesdas), the proportion of people diagnosed with Diabetes Mellitus (DM) was $6.9 \%$ of the total population, which is approximately $12,191,564$ people with age $>15$ years old were diagnosed DM in Indonesia in the year 2013. Data from International Diabetes Federation (IDF) showed that people with DM kept on rising and Indonesia was in the 7th place for the country with the most people with DM from 2013 to 2015 (Indonesia, 2015; Atlas, 2015).

The cost of treatment for DM based on IDF data for the South East Asia region was around 106 billion USD per year and 698-1246 USD per person. The Indonesian
Endocrinology Society (Perkeni) reported that DM main problem in Indonesia is not-routinely taking antidiabetes drugs or insulin injection. According to Perkeni, it is because of the limited availability of hypoglycemic drugs in the public health center. Also, problem-related to DM is the lack of access to the health centers, public health center facilities and infrastructure for people with DM in Indonesia (Soewondo et al., 2013). In handling people with DM, one of the efforts of doctors in Indonesia is to utilize herbal therapy as a complementary therapy (Joeliantina et al., 2016; 2019). Complications to several organs could be found if DM was not well treated. Nephropathy is one of DM complications in the kidney (Chawla et al., 2016; Targher et al., 2018).

$\mathrm{DM}$ is categorized as a degenerative disease. The main problem in degenerative disease is damaged 
healthy cells in the body caused by free radicals (Ahmad et al., 2017). These damaged cells make them not able to work appropriately as their function and structure. These free radicals originated from the Reactive Oxygen Species (ROS) have unpaired electron, thus making them unstable (Asmat et al., 2016). Thus, antioxidant agents tend to be ROS scavengers that are needed to prevent cell damage due to oxidative stress inside our body. Some natural bioactive compounds from plants are believed to have antioxidant activities (Altemimi et al., 2017).

Vernonia amygdalina is popular as an African plant in Indonesia. Its leaf is rich in antioxidant substances (Iwo et al., 2017). It contains many nutrients and chemical compounds, including protein, fiber, carbohydrate fatty acids, carotenoid acid, calcium, flavonoids, alkaloids, saponins, terpenoids, tannins, glycosides, anthraquinones and luteolin (Ojimelukwe and Amaechi, 2019). This plant has been used empirically by some people for various diseases, including anticancer drugs, preventing heart disease, lowering cholesterol, preventing stroke, lowering blood sugar, antibacterial digestive disorders and as an antioxidant (Sh et al., 2018; Agbogidi and Akpomorine, 2013). However, the effect of $V$. amygdalina in the ethanolic extract as an antioxidant is still unclear.

This study aimed to determine the potential of $V$. amygdalina as antidiabetic and antioxidant agents by measuring BGLs, $\mathrm{IC}_{50}$ value and the profiles of phytochemical constituents of $V$. amygdalina using LC-MS analysis.

\section{Materials and Methods}

\section{Materials}

Vernonia amygdalina leaves were obtained from the Research Center for biotechnology, The Indonesian Institute of Sciences in Cibinong.

\section{Sample Preparation}

In about $500 \mathrm{~g}$ of clean $V$. amygdalina leaves were dried. The leaves were diluted in $70 \%$ of $1 \mathrm{~L}$ ethanol. The leaves were soaked for three days and filtered. The filtrate was evaporated at $55^{\circ} \mathrm{C}$ using a rotary evaporator. The final weight was 102.5 grams, with a yield of $20.5 \%$.

\section{Ethanolic Extraction of V. amygdalin Leaves}

The dried plant sample was macerated with $96 \%$ ethanol for $24 \mathrm{~h}$ in a closed vessel, then filtered. This extraction was once repeated in $500 \mathrm{~mL}$. The ethanolic extract was evaporated with a rotary evaporator and obtained as a concentrated extract.

\section{Antioxidant Activity Analysis Using DPPH Method}

In the amount of $4 \mathrm{mg}$ sample was diluted in $4 \mathrm{~mL}$ methanol resulting the final extract concentration of $1000 \mu \mathrm{g} / \mathrm{mL}$ and divided into five concentrations (20,40, 60,80 and $100 \mu \mathrm{g} / \mathrm{mL}$ ) and were added with $0.5 \mathrm{~mL}$ DPPH solution ( $1 \mathrm{~mL}$ in methanol) and vortexed them. The mixed solutions were incubated $30 \mathrm{~min}$. at room temperature. The absorbance was measured at $515 \mathrm{~nm}$ using spectrophotometer UV-Vis.

The calculation of DPPH scavenging inhibition was determined as follow:

$$
\text { DPPH scavenging inhibition }(\%)=\left[1-\left(\frac{A s}{A 0}\right) \times 100 \%\right]
$$

where, As was the absorbance of the sample and Ao was the absorbance of the blank solution. The $\mathrm{IC}_{50}$ values were obtained as a percentage from the linear regression equation.

\section{Bioactive Compound Profiling by LC-MS}

Mass spectrometry was performed on an LC-MS Xevo, G2-XS QTof (waters ms technologies). The ionization type was Electrospray Ionization (ESI). The scan range was from 100 to $1200 \mathrm{~m} / \mathrm{z}$. The capillary and cone voltage was set at 0.8 and $30 \mathrm{kV}$, respectively and was used positive electron spray mode. The desolvation gas was set to $1000 \mathrm{~L} / \mathrm{h}$ at a $500^{\circ} \mathrm{C}$. The cone gas was set to $50 \mathrm{~L} / \mathrm{h}$ and the source temperature was set to $120^{\circ} \mathrm{C}$ (Tang et al., 2016).

The Ultra-high Performance Liquid Chromatography (UPLC) analysis was performed using a water acquity ultra-performance LC system. Chromatographic separation was carried out on an ACQUITY UPLC HSS T3 column $(100 \times 2.1 \mathrm{~mm}, 1.7 \mu \mathrm{m})$ at a column temperature of $40^{\circ} \mathrm{C}$. The mobile phase consisted of solvent A $(0.1 \%$ formic acid in the water, $\mathrm{v} / \mathrm{v})$ and solvent B (0.1\% formic acid in acetonitrile), with gradient polarity from 95:0.5 (A: B) to 0.5:95 (A: B). The flow rate was set at $0.3 \mathrm{~mL} / \mathrm{min}$. The column and autosampler were maintained at 40 and $20^{\circ} \mathrm{C}$, respectively. The injection volume was $1 \mu \mathrm{L}$. The data acquisition and processing were performed using UNIFI. The parameter used was Retention Time (RT) in the range of 1-15 min.

\section{Preparation of In-Vitro Antidiabetic Experiment}

The rat groups were designed as listed in Table 1. The rat models were given pellets and water ad libitum. Each group of rats was placed in a cage that was kept at room temperature. 
Table 1: Rat group of $V$. amygdalina leaf extract treatments

\begin{tabular}{lllll}
\hline Rat group & $\begin{array}{l}\text { Number of } \\
\text { rat/group }(\mathrm{n})\end{array}$ & $\begin{array}{l}\text { Induced by toxic } \\
\text { agent }(3 \mathrm{~g} / \mathrm{kg} \mathrm{BW})\end{array}$ & Treatment & $\begin{array}{l}\text { Treatment dose } \\
(\mathrm{mg} / \mathrm{kg} \mathrm{BW})\end{array}$ \\
\hline Normal (NG) & 4 & - & - & - \\
Positive Control (PC) & 4 & A single-dose alloxan & Metformin & 200 \\
Negative Control (NC) & 4 & A single-dose alloxan & Aquadest & - \\
Sample treatment 1 (VA1) & 4 & A single-dose alloxan & POS extract & 200 \\
Sample treatment 2 (VA2) & 4 & A single-dose alloxan & POS extract & 400 \\
Sample treatment 3 (VA3) & 4 & A single-dose alloxan & POS extract & 600 \\
\hline
\end{tabular}

\section{Data Analysis and Management}

Data collected from the normality test by using the Shapiro-Wilk test. If the data was not significant with the normal distribution analyzed by a one-way ANOVA test $(p>0.05)$, it indicated normality. For data with abnormal distribution $(p<0.05)$, it could be analyzed using the Kruskal Wallis test. If significant differences were found, additional analysis was performed using the Post Hoc test $(p<0.05)$ to see which groups had differences. Observations of rat kidney histopathologies were observed qualitatively by looking at the differences of each treatment group.

\section{Results and Discussion}

The ethanolic extraction of $V$. amygdalin leaf sample was yielded at $20.015 \mathrm{~g}(4.003 \%)$ from $500 \mathrm{~g}$ of dried $V$. amygdalin leaf sample.

In this study, the measurement results of the value of linear regression between concentration and percent inhibition of DPPH were obtained with a value of $y=$ $0.58 \mathrm{x}-0.734$ with $R^{2}=0.996$. Meanwhile, the linear regression value between concentration and percent inhibition of quercetin was $y=5.471 \mathrm{x}+15.382$ with $R^{2}=$ 0.997. Thus, the correlation between the percent inhibition of DPPH and sample concentration has been analyzed, as shown in Table 2.

A compound expressed as it is active if the $\mathrm{IC}_{50}$ value $<50 \mathrm{ppm}$, strong if the $\mathrm{IC}_{50}$ value is between $50-100$ $\mathrm{ppm}$, it is moderate if the $\mathrm{IC}_{50}$ value is between 101-250 ppm while it is weak if $\mathrm{IC}_{50}$ value is $251-500$ and inactive above 500 ppm (Jun et al., 2003).

The results of the data percentage decrease in fasting blood glucose levels. After normality was collected and tested, the data was normally distributed (Table 3).

\section{Alloxan Injection and Treatment}

After being fasted for $12 \mathrm{~h}$, rats were injected intraperitoneally with alloxan at a dose of $120 \mathrm{mg} / \mathrm{kg}$ BW. According to each treatment group, rats were treated for 16 days using a syringe inserted into the mouth of a mouse. Examination of blood glucose levels was done after giving the plant extract treatments (Abel-Salam, 2012; Handayani et al., 2020).
Rat blood was collected intravenously on the tip of the rat tail. Checking blood glucose levels was done in the first $12 \mathrm{~h}$ every four days. The instrument used for checking blood glucose levels was an easy touch glucometer with a strip inserted with the rat blood. The percentage of blood glucose levels was calculated with the formula below:

$$
P D B G L=\frac{G o-G t}{G o} \times 100 \%
$$

Where:

Go $\quad=$ Blood glucose levels before being treated

$G t \quad=$ Blood glucose levels after being treated

$P D B G L=$ Percentage decrease in blood glucose level

\section{Preparation and Observation of Kidney Histopathology}

Kidney histopathology observation was carried out after 16 days of blood glucose level observation were completed. After the rats were decapitated and dissected, the rat kidneys were taken and put into an organ tube containing $10 \%$ formalin buffer. Furthermore, the taken kidneys were observed using a microscope with Haemotoxylin and Eosin (H\&E) staining to observe histological changes of rat kidneys (Handayani et al., 2020).

Based on the one-way ANOVA test, the value of $p<0.001$ was obtained and showed that $p$ was smaller than 0.05 , which indicated a difference between groups. Next, a homogeneity test was performed and the results showed that the data were not homogeneous with a value of $p=0.013(p=0.05)$, as shown in Table 3 .

It showed the group data has different variants. Furthermore, the Post Hoc test was utilized to compare each plant treatment group at different dosages. It found that the groups of positive control and plant extracts $(200,400$ and $600 \mathrm{mg} / \mathrm{kg} \mathrm{BW})$ showed significantly different in the normal group $(p<0.001)$.

Table 4 showed that the normal group has a significant difference with the positive dick group and the three dosage groups of $V$. amygdalina leaf extract (200, 400 and $600 \mathrm{mg} / \mathrm{kg} \mathrm{BW})$. Between each group, the dosage of $V$. amygdalina leaf extract did not have a significant difference. 


\section{Kidney Histopathological Observation}

Kidney organs that have been taken from SpragueDawley rats will then be observed using a microscope with the help of Hematoxylin and Eosin (H\&E) staining.

Histological changes were depicted in Fig. 1 showed that the normal group (Fig. 1A) was no significant difference, which meant that both glomerular and proximal tubules from rat kidneys were not observed any damage to their structure. The negative control group (Fig. 1B), the $200 \mathrm{mg} / \mathrm{kg} \mathrm{BW}$ dose group (Fig. 1D) and the 600 $\mathrm{mg} / \mathrm{kg}$ BW dose group (Fig. 1F) showed the presence of proximal tubular necrosis and infiltration of mononuclear cells (lymphocytes and macrophages). Meanwhile, hemorrhage and necrosis of the proximal tubule in the positive control group (Fig. 1C) and the $400 \mathrm{mg} / \mathrm{kg} \mathrm{BW}$ dose group were observed.

Bioactive compound profiles in the Vernonia amygdalina ethanolic leaf extract were successfully investigated using LC-MS. There were eight bioactive compounds identified, as depicted in Fig. 2. The relative molecular weights of all bioactive compounds were also listed in Table 5.

Table 2: Measurement results of absorbance, percentage of inhibition, $\mathrm{IC}_{50}$ value, regression equation of Vernonia amygdalina Del. extract and quercetin using DPPH method

\begin{tabular}{lllll}
\hline Sample & Consentration $(\mathrm{ppm})$ & $\%$ Inhibition & Linear regression equation & $\mathrm{IC}_{50}(\mathrm{ppm})$ \\
\hline Vernonia amygdalina & 20 & 11.406 & $y=0.585 \mathrm{x}-0.734 R^{2}=0.996$ & 86.709 \\
Del. Extract & 40 & 21.094 & & \\
& 60 & 34.625 & & \\
& 80 & 46.560 & & \\
Quercetin & 100 & 57.187 & & \\
& 2 & 25.439 & & \\
& 4 & 38.281 & & \\
& 6 & 48.125 & & \\
& 8 & 59.843 & & \\
& 10 & 69.375 & & \\
\end{tabular}

Table 3: One-way ANOVA test results in decreasing of fasting Blood Glucose Levels (BGLs)

\begin{tabular}{lll}
\hline Groups & \% Fasting BGLs & $p$ \\
\hline Normal & change & $<0.001$ \\
Negative control & $0.38 \pm 3.06$ & $16.89 \pm 22.22$ \\
Positive control & $75.99 \pm 9.68$ & $77.86 \pm 4.33$ \\
Extract $200 \mathrm{mg} / \mathrm{kg} \mathrm{BW}$ & $71.34 \pm 4.52$ & $66.96 \pm 6.54$ \\
Extract $400 \mathrm{mg} / \mathrm{kg} \mathrm{BW}$ & Extract $600 \mathrm{mg} / \mathrm{kg} \mathrm{BW}$ & 6
\end{tabular}

Table 4: The result of Tamhane test in fasting BGL

\begin{tabular}{llll}
\hline No. & Group 1 & Group 2 & $p$ \\
\hline 1 & Normal & Negative control & 0.98 \\
$<0.001^{*}$ & $<0.001^{*}$ \\
$<0.001^{*}$ & $<0.001^{*}$ \\
& & Positive control & Extract $200 \mathrm{mg} / \mathrm{kg} \mathrm{BW}$ \\
& & Extract $400 \mathrm{mg} / \mathrm{kg} \mathrm{BW}$ & 0.11 \\
& & Extract $600 \mathrm{mg} / \mathrm{kg} \mathrm{BW}$ & 0.15 \\
& & Positive control & 0.19 \\
& & Extract $200 \mathrm{mg} / \mathrm{kg} \mathrm{BW}$ & 0.22 \\
& & Extract $400 \mathrm{mg} / \mathrm{kg} \mathrm{BW}$ & 1.00 \\
& & Extract $600 \mathrm{mg} / \mathrm{kg} \mathrm{BW}$ & 1.00 \\
& & Extract $200 \mathrm{mg} / \mathrm{kg} \mathrm{BW}$ & 0.95 \\
& & Extract $400 \mathrm{mg} / \mathrm{kg} \mathrm{BW}$ & 0.73 \\
5 & & Extract $600 \mathrm{mg} / \mathrm{kg} \mathrm{BW}$ & 0.43 \\
& & Extract $400 \mathrm{mg} / \mathrm{kg} \mathrm{BW}$ & 0.99 \\
\hline
\end{tabular}

* was significantly different $(p<0.05)$ 
Fatmawaty Yazid et al. / OnLine Journal of Biological Sciences 2020, 20 (4): 190.200

DOI: 10.3844/ojbsci.2020.190.200

Table 5: The relative molecular weight of bioactive compound in Vernonia amygdalina leaf extracts

\begin{tabular}{lll}
\hline Compound name & Observed mass (m/z) & Neutral mass (Da) \\
\hline 4-O-Caffeoylquinic acid & 355.1024 & 354.09508 \\
5-Hydroxy-6,4'-dimethoxy-flavone-7-O- $\beta$-D-glucopyranoside & 499.1242 & 476.13186 \\
5-O-Methylvisamminol & 291.1232 & 290.11542 \\
Azedarachin C & 609.2715 & 586.27780 \\
Daturametelin C & 469.2946 & 468.28757 \\
Luteolin-7-O-glucuronide & 463.0873 & 462.07983 \\
Trigonelline & 138.0551 & 137.04768 \\
25(S)-Ruscogenin & 453.2994 & 430.30831 \\
\hline
\end{tabular}
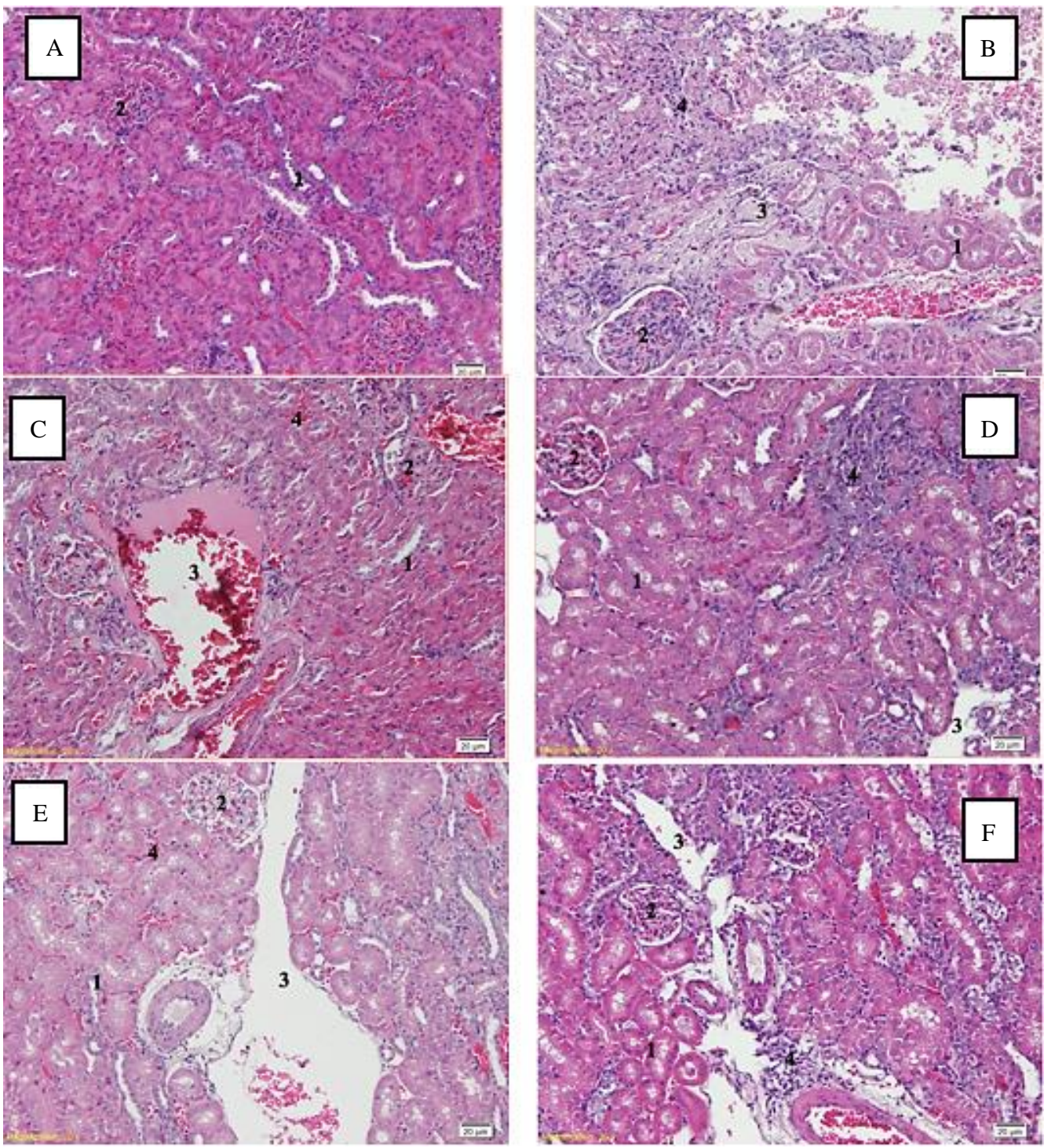

Fig. 1: Histological changes in liver cells using H\&E staining: (A) normal group: There were no specific abnormalities; (B) negative control group: There were proximal tubular necrosis, infiltration of mononuclear cells (lymphocytes and macrophages); (C) positive control groups: Hemorrhage and tubular necrosis proximalis; (D) group of $200 \mathrm{mg} / \mathrm{kg}$ BW dosage: Proximal tubular necrosis and infiltration of mononuclear cells (lymphocytes and macrophages); (E) group of $400 \mathrm{mg} / \mathrm{kg} \mathrm{BW}$ dosage: Proximal tubular necrosis and inflammation of mononuclear cells (lymphocytes and macrophages); (F) group of $600 \mathrm{mg} / \mathrm{kg}$ BW dosage. proximal tubular necrosis and infiltration of mononuclear cells (lymphocytes and macrophages). $1=$ proximal tubule, 2 = glomerolus. 3 = proximal tubular necrosis, 4 = infiltration of mononuclear cells (lymphocytes and macrophages) 


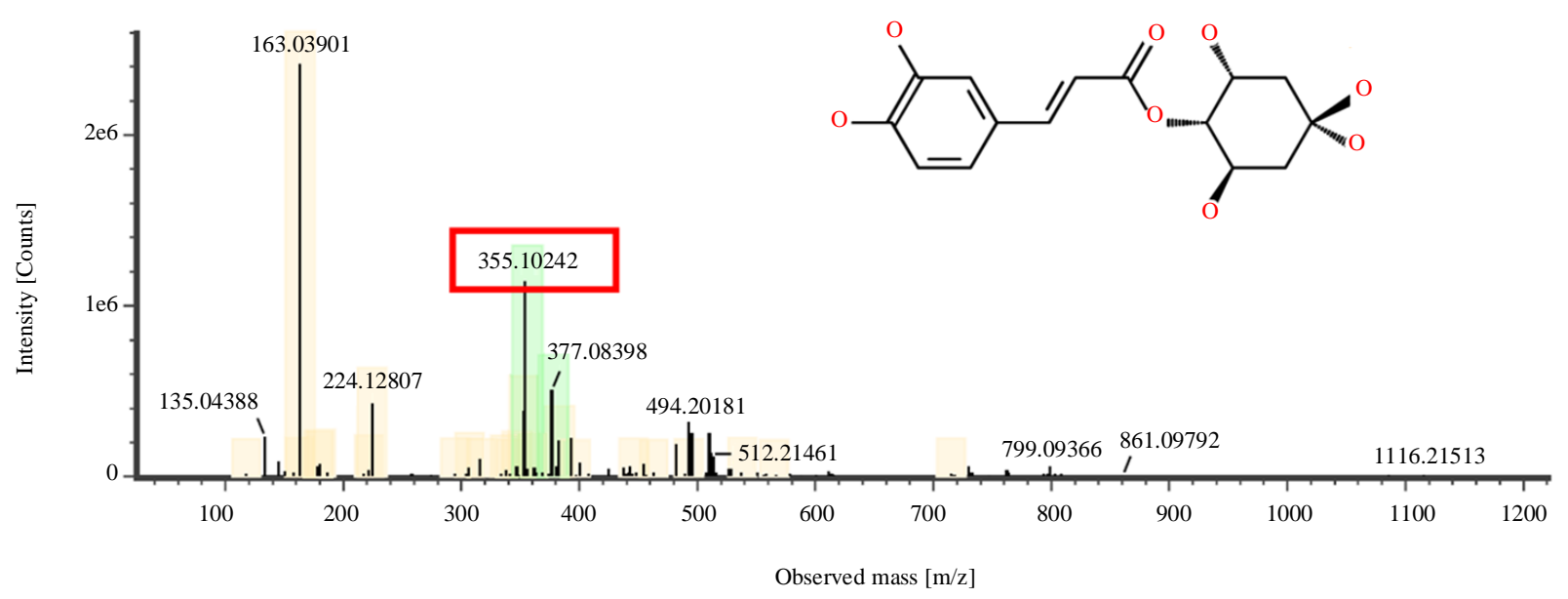

(a)

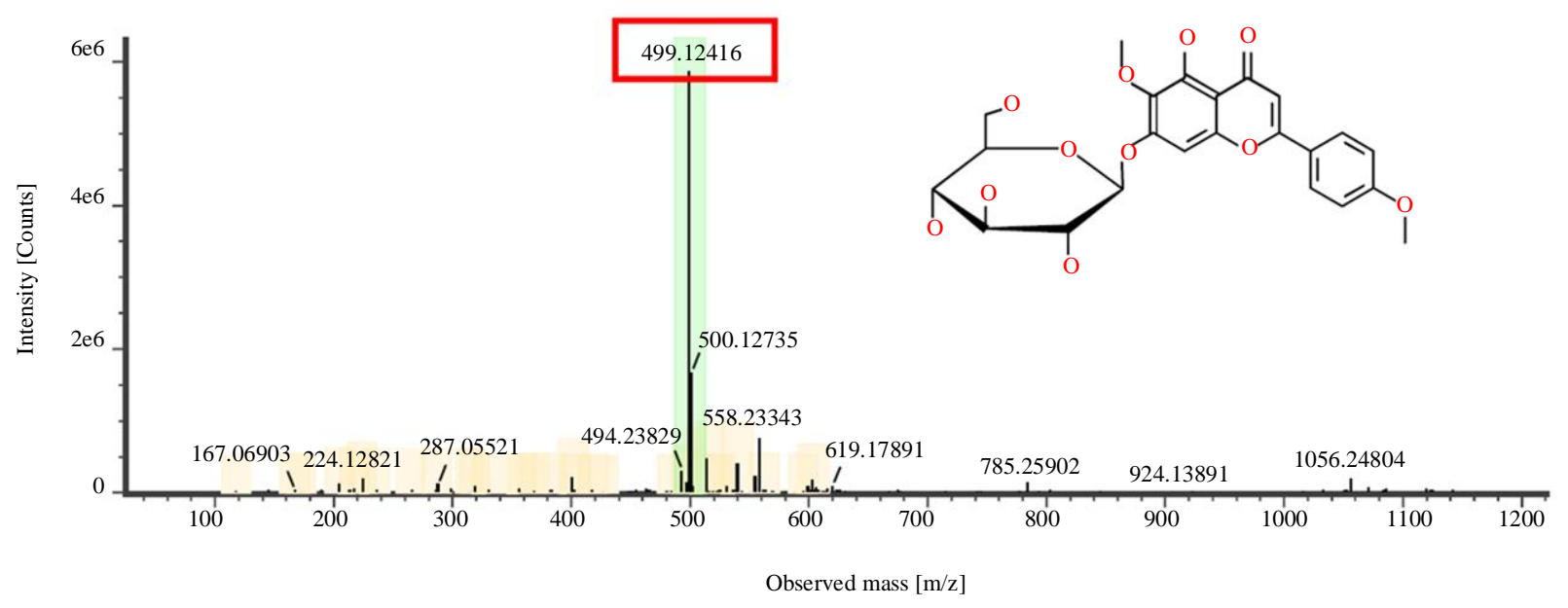

(b)

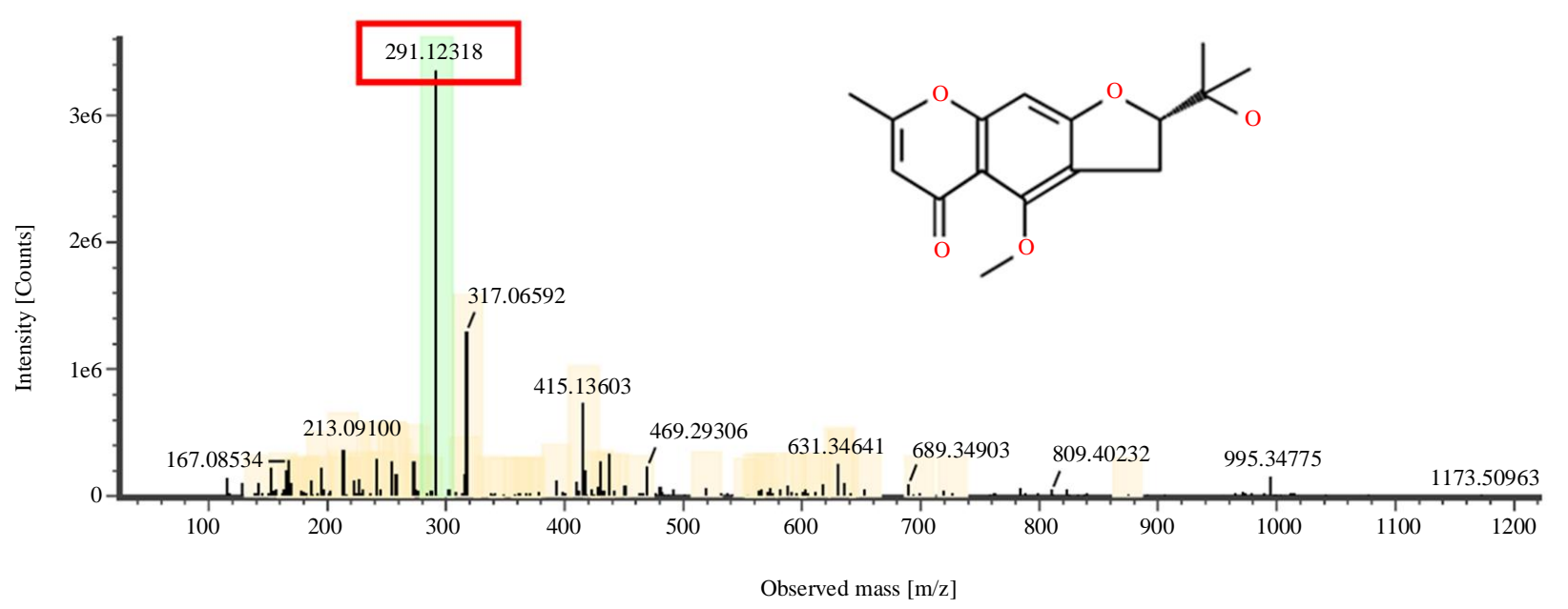

(c) 


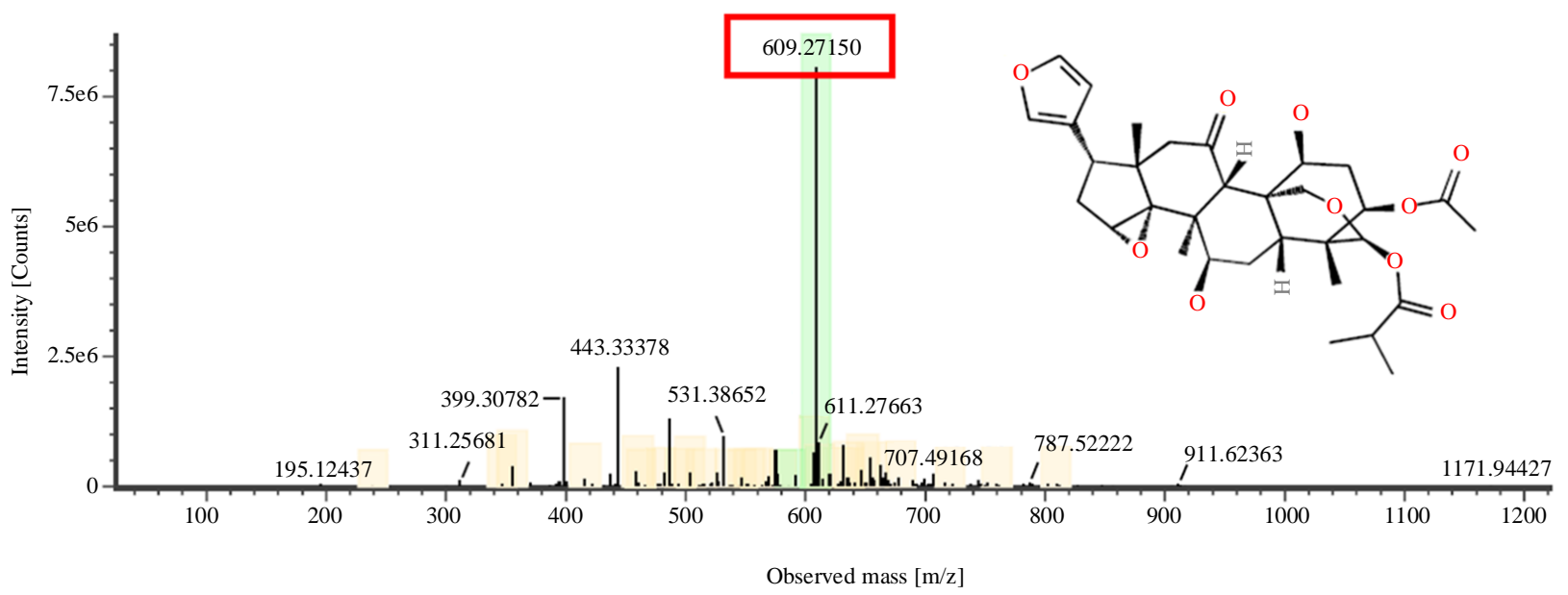

(d)

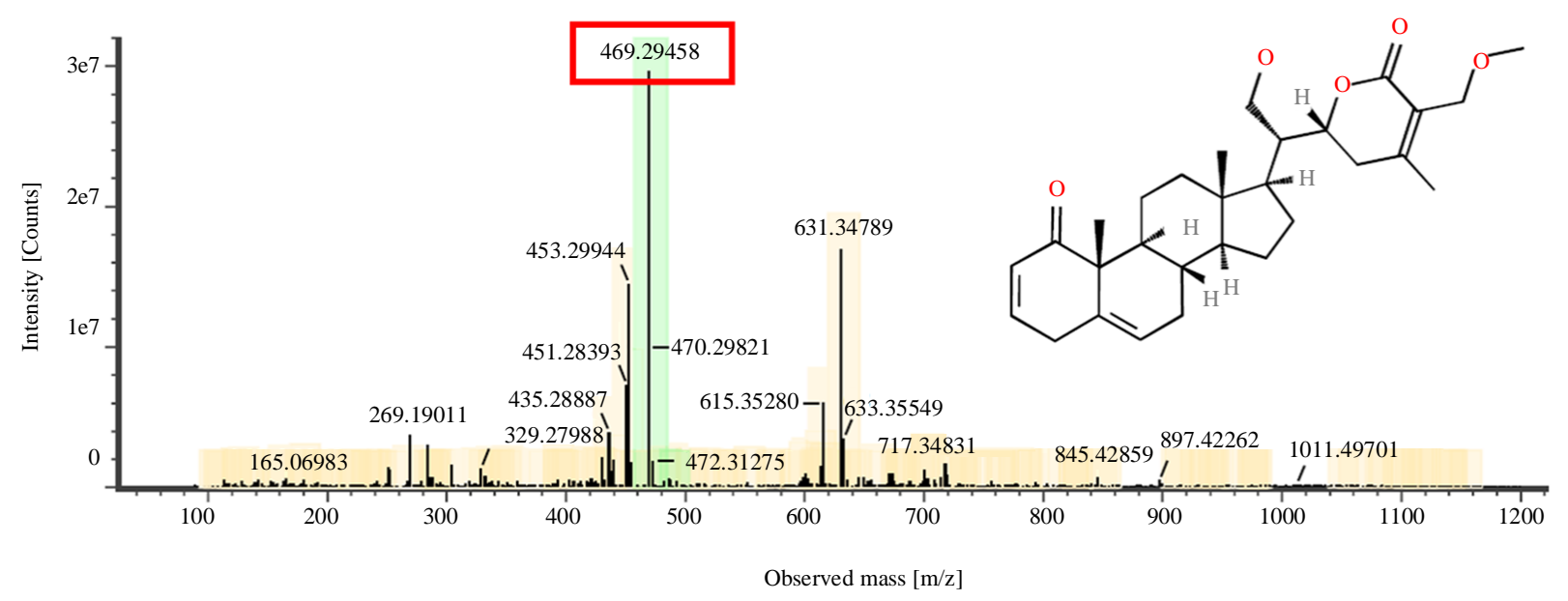

(e)

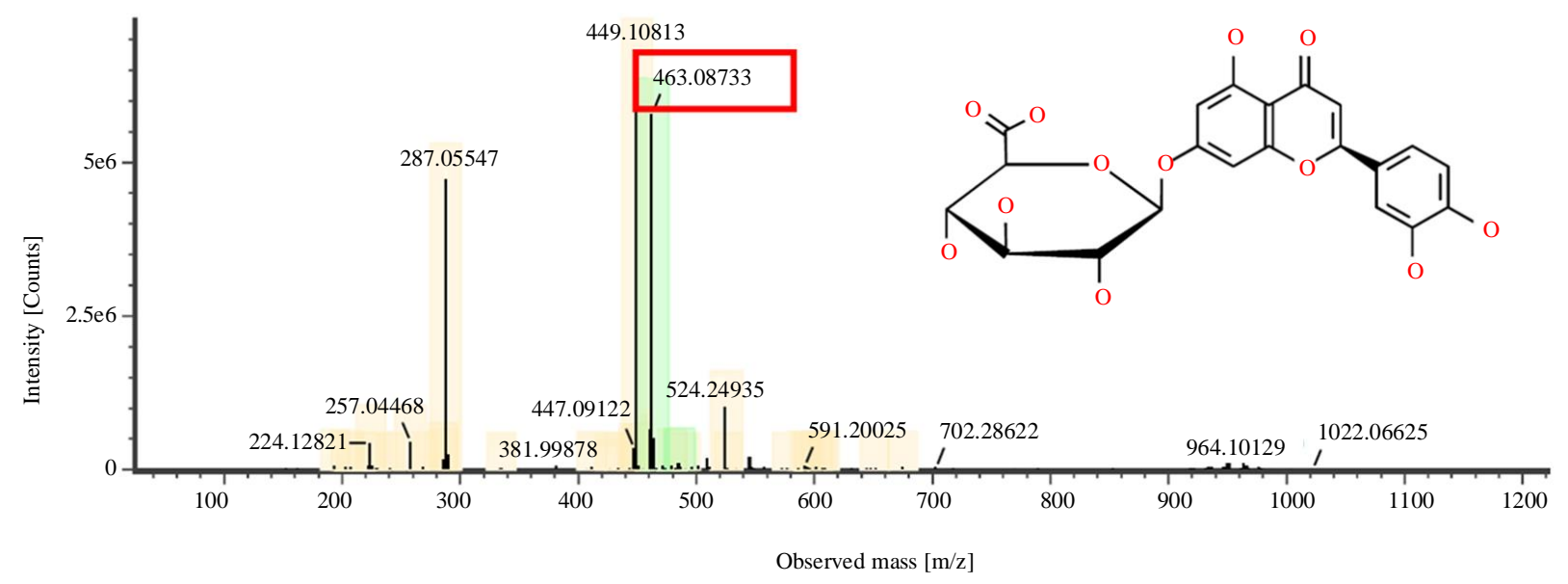

(f) 


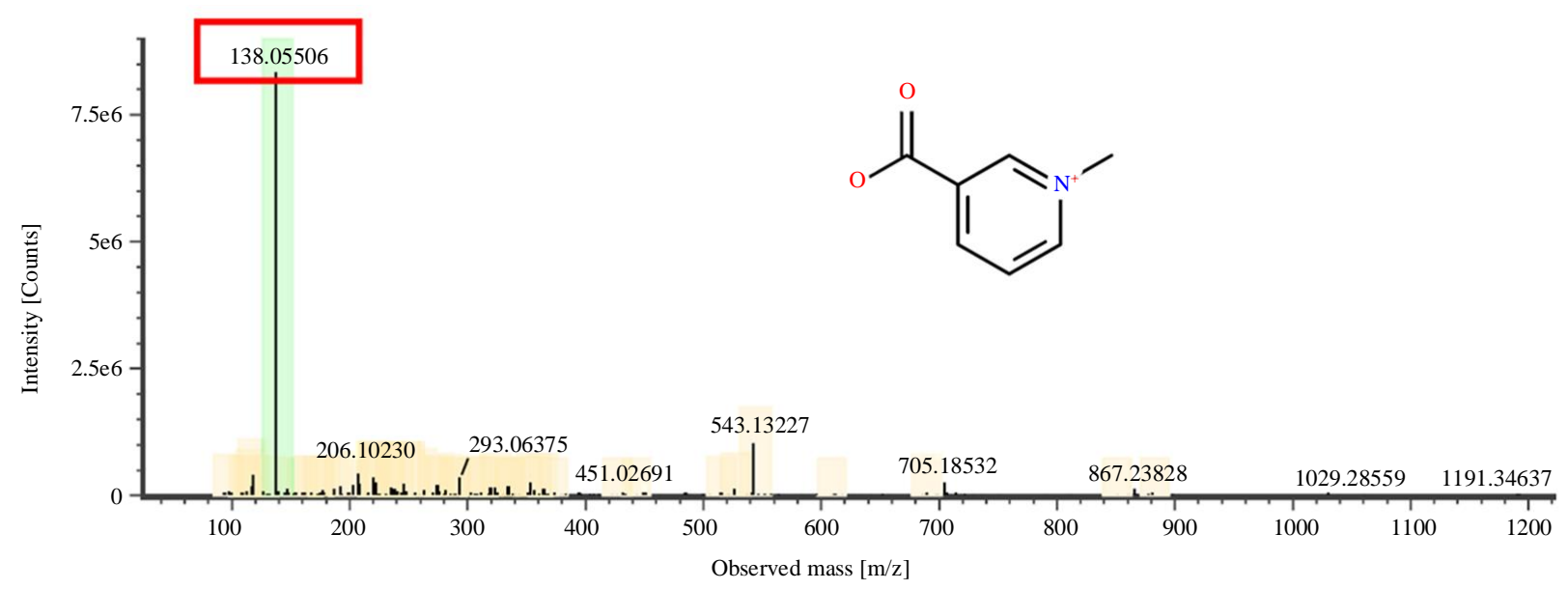

(g)

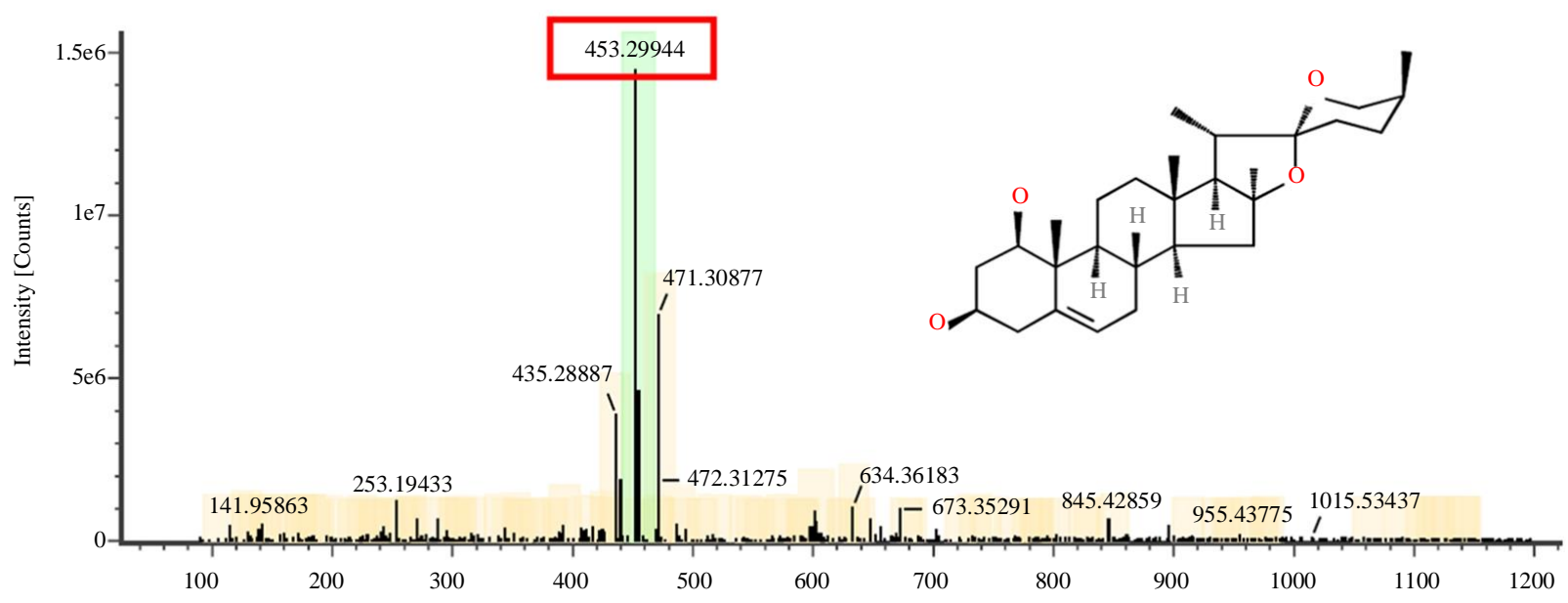

(h)

Fig. 2: LC-MS profile of bioactive compounds in Vernonia amygdalina ethanolic leaf extract. (a) 4-O-caffeoylquinic acid; (b) 5hydroxy-6,4'-dimethoxy-flavone-7-O- $\beta$-D-glucopyranoside; (c) 5-O-methylvisamminol; (d) azedarachin C; (e) daturametelin C; (f) luteolin-7-O-glucuronide; (g) trigonelline; (h) 25(S)-ruscogenin. The red boxes are the observed mass (m/z) of the bioactive compounds

\section{Effect of V. amygdalina Leaf Extract on Fasting Blood Glucose Levels}

In this study, an antidiabetic activity was observed by observing a decrease in fasting blood glucose levels in Sprague-Dawley rats. Based on the results of previous studies, extracts from $V$. amygdalina leaves have several ingredients, such as luteolin, saponins and tannins (Asante et al., 2016). The antidiabetic effect of $V$. amygdalina leaf extract was an increase in GLUT-4 (Glucose Transporter-4) translocation and glycogenesis and played a role in inhibiting gluconeogenic enzymes such as Glucose-6-Phosphatase (G6Pase) (Ong et al., 2011). Luteolin is known to have the ability to inhibit the enzymes $\alpha$-glucosidase and $\alpha$-amylase (function to catalyze the hydrolysis of internal alpha-1,4-glucosidic linkage contained in polysaccharides), so that it functions to reduce Post-Prandial Hyperglycemia (PPHG) (Asante et al., 2016; Johnson et al., 2014; Ong et al., 2011).

Tannin is a polyphenol compound with a strong binding ability and can precipitate proteins, amino acids and alkaloids. Tannins are classified into two types, namely condensed tannins and hydroxylated tannins (Dai et al., 2020). It can also inhibit the enzyme activities of $\alpha$-amylase and $\alpha$-glucosidase (Li et al., 2018). Tannins have benefit in slowing down glucose absorption in the small intestine and producing insulin-like effects in insulin-sensitive tissues. It reduces blood glucose levels and regulates the antioxidant environment in cells (Asante et al., 2016; Kunyanga et al., 2011; Laddha and Kulkarni, 2019). 
The saponins content is known to reduce blood glucose levels by reducing oxidative stress and has an antidiabetic activity to stimulate insulin secretion and action and pancreatic beta-cell regeneration (El Barky et al., 2016). In addition, saponins can also reduce gluconeogenesis by inhibiting the enzymes Glucose-6phosphatase (G6Pase) and fructose-1,6-bisphosphate (Laddha and Kulkarni, 2019; El Barky et al., 2016).

\section{The Effective dose of V. amygdalina Leaf Extract}

The result of fasting BGL decrease showed the highest effectiveness was $200 \mathrm{mg} / \mathrm{kg} \mathrm{BW}$, followed by the groups of positive control, the treatment of 400 and $600 \mathrm{mg} / \mathrm{kg} \mathrm{BW}$, respectively. One-way ANOVA showed a $p$-value $<0.001$. Post hoc tests showed the comparison between the decrease of fasting BGL possessed significant difference $(p<0.05)$, between normal group and positive control, treatment with 200,400 and $600 \mathrm{mg} / \mathrm{kg}$ groups.

\section{Kidney Histopathology}

The condition of hyperglycemia affects kidney tissue, characterized by an increase in Reactive Oxygen Species (ROS), Reactive Nitrogen Species (RNS), lipid peroxidation and protein carbonylation. This state of oxidative stress can induce NF-KB transcription factors, which control the regulation of the activation of various genes that play a role in inflammation, such as cytokines and chemokines (Patel and Santani, 2009). Inflammation that is continuously triggered can cause bleeding (hemorrhagic) in the tissues as in the positive control group and the group with an extract dose of $400 \mathrm{mg} / \mathrm{kg}$ BW (Lenzen, 2008).

In hyperglycemia, ROS and the final glycation product, which increases in diabetes mellitus, is a potent stimulator in chemokines production (Interleukin-8, monocyte-chemoattractant protein 1 and macrophage inflammatory protein-1). The resulting chemokines cause infiltration of macrophages and lymphocytes in the kidneys. This situation triggers an inflammatory response in tissue and cell damage that can develop into fibrosis. It explains the macrophage and lymphocyte infiltration that can be seen in the negative control group histopathological observations, the extract dose group $200 \mathrm{mg} / \mathrm{kg} \mathrm{BW}$ and the extract dose $600 \mathrm{mg} / \mathrm{kg}$ BW (Lim and Tesch, 2012).

A previous study reported that rats with diabetes were observed to have high blood plasma viscosity. This situation causes a decrease in blood flow and perfusion of oxygen to the tissues, resulting in necrosis in various organs, including the kidneys. In the kidney, tubular epithelial tissue undergoes cell degeneration and turns into connective tissue, resulting in a state of necrosis (Andreucci et al., 2014). It explained the results of histopathological observations in the form of necrosis in the proximal tubules found in all groups except the normal group.

\section{The Relationship of V. amydalina Leaves Extract to Renal Histopathology}

The content of luteolin can increase the activity of Superoxide Dismutase (SOD), Glutathione Peroxide (GPx), Catalase (CAT) and Glutathione Reductase (GRed). SOD as the first line in fighting free radicals and oxidative stress with GSH together with glutathione peroxidase serves to reduce the level of oxidative stress that arises due to hyperglycemia by reducing (Hydrogen peroxide) $\left(\mathrm{H}_{2} \mathrm{O}_{2}\right)$ to (water) $\left(\mathrm{H}_{2} \mathrm{O}\right)$ and (oxygen) $\left(\mathrm{O}_{2}\right)$. A decrease in oxidative stress can also reduce the risk of inflammation in cells (Adeoye et al., 2018). In addition, luteolin affects increasing the expression of Heme Oxygenase-1 (HO-1). HO-1 has functioned as an antioxidant and cytoprotectant (Sangeetha, 2019). The administration of saponins showed improvement in kidney creatinine levels, which could prevent the incidence of nephropathy due to diabetes (Wang et al., 2019). Therefore, luteolin and saponin function to prevent inflammation, kidney tissue destruction and nephropathy (Ojimelukwe and Amaechi, 2019; Sangeetha, 2019; Wang et al., 2019).

Although extracts from the leaves of $V$. amygdalina contain compounds with nephron-protective effects, the present study showed no improvement in the kidney histological structures. Several factors can be caused, including air, food, drinking water, laboratory conditions, diseases, stress levels and immunity (Ibegbu et al., 2018; Ibrahim et al., 2020).

\section{Conclusion}

The effect of ethanol extract of Vernonia amygdalina Del. leaf in compensating the oxidative stress was evident in vitro, shown by the $\mathrm{IC}_{50}$ value $=86.709 \mathrm{ppm}$, which was categorized as vigorous antioxidant agent and it was found eight components that contained in $V$. amygdalina Del. based on the LC-MS analysis that contributed as anioxidant agents. This plant leaf extract could reduce blood glucose levels in group of hyperglycemic rats. An effective dose in reducing blood glucose levels of $200 \mathrm{mg} / \mathrm{kg} \mathrm{BW}$. Based on histopathological results, the extract administration did not show improvement by showing the proximal tubule necrosis in all treated groups other than the normal group. Further investigation is needed to find the optimal dose for histological improvement.

\section{Acknowledgment}

We would like to express our gratitude to the Department of Chemistry, Faculty of Medicine, Universitas Indonesia, Balai Penelitian Tanaman Rempah dan Obat (Balittro) and Animal Experiment and Toxicology Laboratory of the Indonesian Ministry of Health, which have supported this research. 


\section{Funding Information}

This research was supported by PUTI UI Saintekes 2020 grant.

\section{Author's Contributions}

Fatmawaty Yazid, Nina Bonita Hasanah, Rosmalena, Muhammad Hanafi and Vivitri Dewi Prasasty: Performed the experiments, analyzed the data, preparation of the manuscript for publication.

Fatmawaty Yazid: Designed the experiments, principal investigator for the implementation of research work.

\section{Ethics}

This manuscript has not been published, presented elsewhere and is not under consideration by another journal. All the authors have approved the manuscript and agree in submitting to OnLine Journal of Biological Sciences. There is no conflict of interest in this matter.

The animal study has been approved by The Research Ethical Committee of the Faculty of Medicine, Universitas Indonesia (Ethical Letter No: 096/UN2.F1/etik/PPM.00.02/2019).

\section{References}

Abel-Salam, B. K. (2012). Immunomodulatory effects of black seeds and garlic on alloxan-induced diabetes in albino rat. Allergologia et immunopathologia, 40(6), 336-340.

Adeoye, A., Oyagbemi, A., Omobowale, T., Adedapo, A. D., Ayodele, A. E., \& Yakubu, M. T. (2018). Nephroprotective effects of Vernonia amygdalina in alloxan-induced diabetes in rats. International Journal of Biochemistry Research \& Review, 21(1), 1-15.

Agbogidi, O. M., \& Akpomorine, M. O. (2013). Health and nutritional benefits of bitter leaf (Vernonia amygdalina Del.). Int JA PS. BMS Hetero Group J, 2, 164-70.

Ahmad, W., Ijaz, B., Shabbiri, K., Ahmed, F., \& Rehman, S. (2017). Oxidative toxicity in diabetes and Alzheimer's disease: Mechanisms behind ROS/RNS generation. Journal of biomedical science, 24(1), 76.

Altemimi, A., Lakhssassi, N., Baharlouei, A., Watson, D. G., \& Lightfoot, D. A. (2017). Phytochemicals: Extraction, isolation and identification of bioactive compounds from plant extracts. Plants, 6(4), 42.

Andreucci, M., Faga, T., Pisani, A., Sabbatini, M., \& Michael, A. (2014). Pathogenesis of acute renal failure induced by iodinated radiographic contrast media. Austin J Nephrol Hypertens, 1(1), 1005.
Asante, D. B., Effah-Yeboah, E., Barnes, P., Abban, H. A., Ameyaw, E. O., Boampong, J. N., ... \& Dadzie, J. B. (2016). Antidiabetic effect of young and old ethanolic leaf extracts of Vernonia amygdalina: A comparative study. Journal of diabetes research, 2016.

Asmat, U., Abad, K., \& Ismail, K. (2016). Diabetes mellitus and oxidative stress-A concise review. Saudi pharmaceutical journal, 24(5), 547-553.

Atlas, D. (2015). International diabetes federation. IDF diabetes atlas. Brussels: International Diabetes Federation.

Chawla, A., Chawla, R., \& Jaggi, S. (2016). Microvasular and macrovascular complications in diabetes mellitus: Distinct or continuum?. Indian journal of endocrinology and metabolism, 20(4), 546.

Dai, X., Liu, Y., Zhuang, J., Yao, S., Liu, L., Jiang, X., ... \& Gao, L. (2020). Discovery and characterization of tannase genes in plants: Roles in hydrolysis of tannins. New Phytologist, 226(4), 1104-1116.

El Barky, A. R., Hussein, S. A., Alm-Eldeen, A. A., Hafez, Y. A., \& Mohamed, T. M. (2016). Antidiabetic activity of Holothuria thomasi saponin. Biomedicine \& Pharmacotherapy, 84, 1472-1487.

Handayani, S. I., Dewi, S. N., Stephanie, M., Nurbaya, S., \& Prasasty, V. D. (2020). The Effect of Annona Muricata Leaf Ethanolic Extract on Insulin Expression and Glucagon-Like Peptide-1 Level in Alloxan-Induced Mice. Systematic Reviews in Pharmacy, 11(7), 363-370.

Ibegbu, M. D., Nnaemeka, E. J., Ikele, I. T., \& Nwachukwu, D. C. (2018). Anti-hyperglycaemic and anti-hyperlipidemic effect of aqueous leaf extract of Vernonia amygdalina in Wistar rats. African Journal of Pharmacy and Pharmacology, 12(19), 231-239.

Ibrahim, N. H., Ellamie, A. M., Fouda, W. A., \& Younis, F. E. (2020). Physiological and Behavioral Responses of Growing Barki Ram Lambs Exposed to Heat Stress and Fed Brown Seaweed as Additives under Semi-Arid Conditions. Journal of Animal and Poultry Production, 11(2), 55-65.

Indonesia, P. E. (2015). Pengelolaan dan pencegahan diabetes melitus tipe 2 di Indonesia. $\mathrm{Pb}$. Perkeni.

Iwo, M. I., Sjahlim, S. L., \& Rahmawati, S. F. (2017). Effect of Vernonia amygdalina Del. leaf ethanolic extract on intoxicated male Wistar rats liver. Scientia pharmaceutica, 85(2), 16.

Joeliantina, A., Agil, M., Qomaruddin, M. B., \& Soedirham, O. (2019). Family Support for Diabetes Self-care Behavior in T2DM Patients who Use Herbs as a Complementary Treatment. MedicoLegal Update, 19(1), 238-243.

Joeliantina, A., Agil, M., Qomaruddin, M. B., Jonosewojo, A., \& Kusnanto, K. (2016). Responses of diabetes mellitus patients who used complementary medicine. International Journal of Public Health Science, 5(4), 367-374. 
Johnson, M., SM, A., \& Godonu, K. G. (2014). Hypoglycemic and hepatoprotective effects of Vernonia Amygdalina (Bitter Leaf) and its effect on some biochemical parameters in alloxan-induced diabetic male albino rats. Science Journal of Biotechnology, 2014.

Jun, M., Fu, H. Y., Hong, J., Wan, X., Yang, C. S., \& Ho, C. T. (2003). Comparison of antioxidant activities of isoflavones from kudzu root (Pueraria lobata Ohwi). Journal of food science, 68(6), 2117-2122.

Kunyanga, C. N., Imungi, J. K., Okoth, M., Momanyi, C., Biesalski, H. K., \& Vadivel, V. (2011). Antioxidant and antidiabetic properties of condensed tannins in acetonic extract of selected raw and processed indigenous food ingredients from Kenya. Journal of food science, 76(4), C560-C567.

Laddha, A. P., \& Kulkarni, Y. A. (2019). Tannins and vascular complications of diabetes: An update. Phytomedicine, 56, 229-245.

Lenzen, S. (2008). The mechanisms of alloxan-and streptozotocin-induced diabetes. Diabetologia, 51(2), 216-226.

Li, K., Yao, F., Du, J., Deng, X., \& Li, C. (2018). Persimmon tannin decreased the glycemic response through decreasing the digestibility of starch and inhibiting $\alpha$-amylase, $\alpha$-glucosidase and intestinal glucose uptake. Journal of agricultural and food chemistry, 66(7), 1629-1637.

Lim, A. K., \& Tesch, G. H. (2012). Inflammation in diabetic nephropathy. Mediators of inflammation, 2012.

Ojimelukwe, P. C., \& Amaechi, N. (2019). Composition of Vernoniaamygdalina and its Potential Health Benefits. International Journal of Environment, Agriculture and Biotechnology, 5(6).
Ong, K. W., Hsu, A., Song, L., Huang, D., \& Tan, B. K. H. (2011). Polyphenols-rich Vernonia amygdalina shows anti-diabetic effects in streptozotocin-induced diabetic rats. Journal of ethnopharmacology, 133(2), 598-607.

Patel, S., \& Santani, D. (2009). Role of NF- $\kappa$ B in the pathogenesis of diabetes and its associated complications. Pharmacological Reports, 61(4), 595-603.

Sangeetha, R. (2019). Luteolin in the management of type 2 diabetes mellitus. Current Research in Nutrition and Food Science Journal, 7(2), 393-398.

Sh, P., Jacob, S. O., Usman, A. A., Auta, M., \& Olutoye, M. A. (2018). Development and characterisation of a multifunctional hybrid nano-flora composite for the prevention and management of cancer, diabetes, blood pressure and stroke.

Soewondo, P., Ferrario, A., \& Tahapary, D. L. (2013). Challenges in diabetes management in Indonesia: A literature review. Globalization and health, 9(1), 63.

Tang, J. F., Li, W. X., Tan, X. J., Li, P., Xiao, X. H., Wang, J. B., ... \& Meng, F. (2016). A novel and improved UHPLC-QTOF/MS method for the rapid analysis of the chemical constituents of Danhong injection. Analytical Methods, 8(14), 2904-2914.

Targher, G., Lonardo, A., \& Byrne, C. D. (2018). Nonalcoholic fatty liver disease and chronic vascular complications of diabetes mellitus. Nature reviews endocrinology, 14(2), 99.

Wang, Q., Wu, X., Shi, F., \& Liu, Y. (2019). Comparison of antidiabetic effects of saponins and polysaccharides from Momordica charantia L. in STZ-induced type 2 diabetic mice. Biomedicine \& Pharmacotherapy, 109, 744-750. 